\title{
Phenomenological Exploration of Cultural Difference
}

\author{
Yu Chung-Chi \\ National Sun Yat-sen University, Taiwan
}

\begin{abstract}
How phenomenology deals with the problematic of cultural difference? The present paper explores this question in the frameworks of Edmund Husserl (1859-1938) and Alfred Schutz (1899-1959). Husserl dealt with the problem of cultural difference and cultivated the position of cultural universalism in his phenomenological thinking. He insisted on the idea of universalism that originates in ancient Greek and he demonstrated this idea of universalism through the discourse of the life-world. Even though Husserl does not focus on the issue of cultural difference, yet his notion of appresentation is useful to explicate this issue. Schutz also handled the problematic of cultural difference with help of appresentation, though in implicit manner. Aiming at an exploration of cultural difference on the track of both Husserl and Schutz, the present paper concludes that the concept of appresentation proves to be crucially relevant in this respect.
\end{abstract}

Keywords: Phenomenology, Husserl, Schutz, Heidegger, Cultural Difference, Appresentation

\section{Introduction}

Although the question of cultural difference has never been a main topic in phenomenological philosophy, as it has in the philosophy of culture (Hongladarom, 2001; Taylor, 1994; Mall, 1995; Dallmayr, 1996; Waldenfels, 1997; Holenstein, 1998; Welsch, 1999), ${ }^{1}$ it is not alien at all to some phenomenologists. Husserl, for example, in distinguishing the home-world from the alien-world dealt with the problem of cultural difference implicitly (Husserl, 1973; Steinbock, 1995). Schutz also indirectly addressed the issue of cultural difference when clarifying the notion of the life-world in his theory. However, neither Schutz nor Husserl has directly tackled cultural difference as an explicitly philosophical question or explored the meaning of cultural difference with great intensity, since for Husserl, the one world (die eine Welt) underlies the different home-worlds and, for Schutz, universal symbolism lays the common ground for all the different life-worlds. Both Husserl and Schutz are more interested in the commonalities of cultures, and leave the problem of cultural difference underdeveloped in their work. In light of this, the question should be raised: How can the explication of cultural difference be construed in phenomenology? (Schutz, 1962) ${ }^{2}$ The author will deal with this question by investigating the issue of cultural objects.

\footnotetext{
Yu Chung-Chi, Ph.D., Professor, Institute of Philosophy, National Sun Yat-sen University, Kaohsiung, Taiwan.

${ }^{1}$ Recent discussions on culture in philosophy have focused on multiculturality, interculturality, or transculturality. See, for example, Charles Taylor (1994); Ram Adhar Mall (1995); Fred Dallmayr (1996); Bernhard Waldenfels (1997); Elmar Holenstein (1998); and Wolfgang Welsch (1999).

2 Dealing with cultural difference philosophically means that I am not concerned with the differences between particular cultures such as the Chinese culture and the European culture and how they differ from each other, for example, with respect to family structure or clothing style. Inquiries of that sort belong to cultural anthropology, social psychology, or cultural psychology. Besides, what I understand to be cultural difference does not only refer to the great cultural traditions like those of China and Europe. I follow Alfred Schutz in holding that cultural difference also exists between different social levels, such as the subculture of the adolescence and old age, between the working class and business people.
} 


\section{Explorations of Cultural Difference}

In order to explore cultural difference in phenomenology, in particular by continuing the basic tendencies of both Husserl and Schutz, we will ask "What is specific to appresentation in this particular context?" and "How can this phenomenological concept be applied to the problem of cultural differences?”.

In a situation in which two things are completely identical, such as "2" and "2", there is no difference. At the other extreme, if two things have no connection at all, for example, "two kilos" and "the blue sky", there is simply no sense in talking about the difference. We assume, therefore, that difference is difference only when two or more distinctive items are compared against a common background, and so appresentation can be aptly used to explain cultural difference. Appresentation is coupled with presentation and together they make a "functional community" (Funktionsgemeinschaft). Presentation (in Schutz: the "appresenting item") is common to all human beings in spite of all kinds of cultural differences, whereas appresentation (in Schutz: the "appresented item") is apparent only to a particular culture. The colour red, for example, can be universally perceived, but this colour may not have the same meaning or evaluation in different cultures. For the Chinese, this colour signifies delight or joyfulness, whereas in another tradition, this colour may be associated with blood and is therefore frightful rather than delightful. As Gurwitsch (1974) put it, every perception has its cultural significance. But the cultural meaning or value-system is different from culture to culture. In the eyes of a Chinese, the colour red would mostly be coupled with a positive value, but this would not necessarily be so for an American. A religious symbol, a cross for example, would stimulate the feeling of holiness for a Christian, but no such feeling would be aroused in a Buddhist. But does it mean that the Chinese and the American perceive different colours and that the Christian and the Buddhist perceive different crosses? To insist that they do would be ridiculous.

The case can obviously be better explained, if we say that, at the level of bare perception, they share something in common, whereas at the cultural level, they have different interpretations. In terms of phenomenological terminology, their appresentational references (in Schutz: “appresented references”) are different, whereas the presentation (in Schutz: "appresenting item”) is the same. Schutz wrote that everyone is, more or less, an expert in a certain field because he/she and a few like him/her possess specific knowledge that other people do not share. This is because of his/her specific personal background. If a person is educated as a medical doctor, he/she would be accustomed to looking at the human body from a medical viewpoint. He/she has knowledge which people with no medical background have no direct access to. Nonetheless, a medical doctor has his/her own professional circle, and within this circle, he/she may feel "at home” with respect to knowledge, that is, he/she can communicate with people in his/her circle more easily. In general, people can also communicate more easily within their own cultural circles.

Every culture has its own traditions, according to which some historical events are highly appreciated. Some cultures celebrate festivals that are absent in other cultures. Such things belong to the stock of knowledge that is commonly shared by the members of this culture but that is alien to strangers. Many things and value-systems are so natural to certain groups of people that they may not be recognized as cultural any more. Is the cultural not natural, and is the natural not always culturally interpreted as Merleau-Ponty has suggested? (Merleau-Ponty, 1962; Lingis, 1986) ${ }^{3}$ We only need to take into consideration that every river and every

\footnotetext{
${ }^{3}$ Merleau-Ponty expressed this point even more clearly when he said: "Moreover the distinction between the two planes (natural and cultural) is abstract, everything is cultural in us (our Lebenswelt is 'subjective') (our perception is cultural-historical) and everything is natural in us (even the cultural rests on the polymorphism of the wild Being)”.
} 
mountain has its own name. But maybe some things seem to be so natural that people forget that these phenomena are, nevertheless, still cultural and, moreover, that they are different from culture to culture. In fact, no culture can claim that its ways of valuation and appresentation are universally valid. Husserl was also aware of the relative value of every cultural world, which he named the "concrete life-world". ${ }^{4}$ But he reminded us of the fact that, no matter how different cultural interpretations are, all human beings nevertheless live in the same life-world because our perceptions remain the same. This is the common world for all. Thus, the life-world can also be described as the "precultural world" (Carr, 1974, p. 195).

Some phenomenologists have found Husserl's conception of the life-world to be untenable. Gurwitsch, for example, insisted that the life-world is essentially a cultural world as well as a practical world. Gurwitsch (1974) explained:

In the life-world we do not encounter-at least not in the first place —-mere corporeal objects, pure perceptual things [...]. What we encounter are cultural objects, objects of value, e.g., works of art, buildings which serve specific purposes, like abodes, places for work, schools, libraries, churches, and so on. (p. 143)

Also,

Accordingly, the life-world, to which we gain access by the subtractive procedure in question, does not consist of mere corporeal objects in the sense just mentioned. On the contrary, it is a world interpreted, apperceived, and apprehended in a specific way. In a word, it is a cultural world, more precisely, the cultural world of a certain sociohistorical group, that of our society at the present moment of history. (p. 20)

What Gurwitsch meant by "substractive procedure" will soon be explained below. For the moment, the author thinks Gurwitsch was right in holding that we encounter cultural objects in the daily life-world, and that all cultures differ from one another. Nevertheless, he has overlooked the phenomenon of cultural difference. Is this because the issue of cultural difference is trivial and therefore irrelevant? Schutz, on the other hand, recognized this problem and discussed this issue with Gurwitsch in their 1950s correspondence. The author strongly believes that so long as we understand the life-world as a cultural world, we can never dismiss the problem of cultural difference. But how are we to interpret cultural difference anyway? Ironically, the Husserlian notion of the life-world or the experiential world might offer us a solid foundation for interpreting cultural difference. We have seen that, without some shared commonality between cultures, we cannot properly discuss the experience of cultural difference. Only when we say that, for example, the Chinese people and the American people perceive the same colour "red" can we compare how differently this colour is evaluated in Chinese and American cultures. And, as hinted at above, the difference can be clarified in terms of appresentation because appresentation is always coupled with presentation, that is, with something that is directly perceived.

As mentioned above, Gurwitsch has criticized the weight Husserl placed on the idea of bare perception, that is, the notion that the perceived world is a product of abstraction and therefore artificial. In this context, we might take into consideration Heidegger's distinction between Vorhandenheit and Zuhandenheit, since Gurwitsch (1974) had referred to it in some passages (p. 19). In Sein und Zeit (Being and Time), Heidegger used three concepts "conspicuousness" (Auffälligkeit), "obtrusiveness" (Aufdringlichkeit), and "obstinacy" (Aufsässigkeit) to explain how something useful might, in the end, simply turn into something for pure perception, something that is distant from our concerns and just shows up as something to look at (Heidegger,

${ }^{4}$ Hua VI, p. 136. 
1993; Macquarrie \& Robinson, 1962). Heidegger also (1993) criticized Descartes in the same way, as the latter viewed the physical world around us as res extensa rather than as an intimate surrounding life-world. This way of treating objects around us is a symptom of the Forgetting of Being (Heidegger, 1993). Although Heidegger did not express it openly, it was not unreasonable for Heidegger to suggest that Husserl had the same tendency, since Husserl laid so much stress on die vorhandende Welt- the bare perception of objects. ${ }^{5}$

Now, the question is: Does Heidegger's criticism hold good for Husserl emphasis on bare perception? The author tends to reject this way of reading Husserl, because bare perception is not a product of scientific abstraction (This is especially true when science, here, refers to the objective natural sciences). We should not forget that Husserl (especially in his transcendental phenomenology) strongly disapproved of modern objective science and suggested a return to the life-world: the world of bare perception that has universally intersubjective validity. Even when we follow Heidegger's distinction between Zuhandenheit and Vorhandenheit, we can see that this criticism is not applicable to Husserl. If Gurwitsch followed Heidegger in this respect, then we have to say that his criticism does not hold good for Husserl, either.

We may contend that, in the life-world, the substratum of perception is simply indispensable. According to Husserl, we must first intentionally perceive a "thing", so that we may locate a specific meaning in it, whatever that meaning is. This understanding of perception might seem questionable in the eyes of Heidegger as well as Gurwitsch, because in a familiar milieu, we may perceive something as a cultural object without further questions. This situation can best be explained in the words of Lester Embree, who wrote: "Familiarity with how the world as we initially encounter it is full of cultural objects equipped with values and uses as well as belief characteristics facilitates reflecting how evidencing can justify believing, valuing and willing” (Embree, 2002, p. 90).

But in the situation of encountering something unfamiliar, we are unable to catch the cultural meaning of "cultural objects" easily, even though we still perceive these objects as intentional objects. In terms of presentation and appresentation (in Schutz: “appresenting” and "appresented”), we may say that each sociohistorical group has its own appresentational system of reference, which is not shared by outsiders. Nevertheless, both the people of the in-group and out-group share the system of perception, or in Schutz's terminology, the apperceptional system. ${ }^{6}$

\section{Conclusion}

It is an obvious fact that our experience of culture today is no longer limited to a single culture. All too often we encounter things that are not easily comprehensible. Should we suggest that they are not cultural? If we recognize something as cultural but cannot explain the functions they serve (for example, the atlatl from an ancient aboriginal Indian tribe in North America [Embree, 1997]), we are encountering the issue of cultural difference. $^{7}$ Therefore, the author holds that the Husserlian conception of perception is more helpful than that

\footnotetext{
${ }^{5}$ Hua IV, p. 186.

${ }^{6}$ Schutz distinguished among apperceptual, appresentational, referential, and contextual or interpretational schemes to explain various orders involved in the appresentaional situation. See CP I, p. 297.

7 Embree in his article “A Gurwitschean Model for Explaining Culture, or How to Use an Atlatl” offered a fictional story about a student of archaeology digging out something with which he is very unfamiliar. He can only describe it as "a stick of wood less than a metre long with a small protuberance at one end" or at most "a piece of equipment of some sort from the caves". Only after inquiring about it with a professor does he come to know that it is a weapon to kill a giant bison or even an elephant (p. 142). Even though Embree concluded that "[a]t the same time, the student (and the reader) can be said to have begun to enter an other cultural world" (p. 143), and remarked that "as a cultural object, i.e., concretely, the moon of the Indians is not the moon of the British” (p. 168), the main theme of his article remains the attempt to explain cultural objects rather than cultural difference.
} 
of Heidegger's and Gurwitsch's. And the author believes that Husserl's phenomenological concept of appresentation can offer us a useful tool to clarify cultural difference. In other words, people from all cultural backgrounds share the level of perception; they all live in the same Husserlian life-world, while, at the same time, possessing their own appresentational schemes and living in their own Schutzian life-world.

Ever since Heidegger marked a distinction between Zuhandenheit and Vorhandenheit, some phenomenologists have been aware that the Husserlian account of life-world experiences does not correspond to actual life-world experiences. As indicated above, the life-world has a cultural aspect, not just a natural aspect. We may consent to this criticism if our life-world experiences take place exclusively within a limited cultural circle and neglect the alternative possibilities. However, this kind of criticism overlooks the obvious fact that we are now living in a multicultural, transcultural, or intercultural world. Thus, the author finds it meaningful to take up the Husserlian position to explain experiences of cultural difference. In our age, we often encounter events, things, or objects that we do not comprehend immediately. They are alien to us because they break with our customary frame of life. But can they be deprived of cultural meaning just because they are difficult to comprehend? To hold this view, one would be taking an ethnocentric position which involves a kind of imperialism that is undesirable in this multicultural and transcultural age. In a time when cultures were suppressed in the past, are striving to win recognition, it is crucial to take the issue of cultural difference seriously and to explicate it in a new light. The author believes that phenomenology, in particular with help of the notion of appresentation, can provide us with a good basis to face this challenge.

\section{References}

Carr, D. (1974). Phenomenology and the problem of history: A study of Husserl's transcendental philosophy. Evanston: Northwestern University Press.

Dallmayr, F. (1996). Beyond orientalism: Essays on cross-cultural encounter. Albany: State University of New York Press.

Embree, L. (1997). A Gurwitschean Model for explaining culture, or how to use an atlatl. In J. C. Evans \& R. S. Stufflebeam (Eds.), To work at the foundations: Essays in memory of Aron Gurwitsch (pp. 141-174). Dordrecht: Kluwer Academic Publishers.

Embree, L. (2002). The constitution of basic culture. Culture and Society: International Journal of Human Sciences, 3, 90.

Gurwitsch, A. (1974). Phenomenology and the theory of science. (L. Embree, Ed.). Evanston: Northwestern University Press.

Heidegger, M. (1993). Sein und Zeit. Tübingen: Max Niemeyer Verlag.

Holenstein, E. (1998). Kulturphilosophische Perspektiven. Frankfurt am Main: Suhrkamp.

Hongladarom, S. (2001). Kulturelle Differenz als kulturelles Konstrukt. In R. Düssel, G. Edel, \& U. Schödlbauer (Eds.), Die Macht der Differenz: Beiträge zur Hermeneutik der Kultur. Heidelberg: Synchron Publishers.

Husserl, E. (1973). Zur Phänomenologie der Intersubjektivität: Erster Teil: 1905-1920 (Husserliana XIII, I. Kern, Ed.). Den Haag: Martinus Nijhoff.

Lingis, A. (Trans.). (1986). The visible and the invisible. Evanston: Northwestern University Press.

Macquarrie, J., \& Robinson, E. (Trans.). (1962). Being and time. New York: Harper \& Row.

Mall, R. A. (1995). Philosophie im Vergleich der Kulturen: Interkulturelle Philosophie_Eine Neue Orientierung Darmstadt: Wissenschaftliche Buchgesellschaft.

Merleau-Ponty, M. (1962). Phenomenology of perception. (C. Smith, Trans.). London: Routledge \& Kegan Paul.

Schutz, A. (1962). Collected papers (Vol. I). The Hague: Martinus Nijhoff.

Steinbock, A. (1995). Home and beyond: Generative phenomenology after Husserl. Evanston: Northwestern University Press.

Taylor, C. (1994). The politics of recognition. In A. Gutmann (Ed.), Multiculturalism: Examining the politics of recognition. Princeton: Princeton University Press.

Waldenfels, B. (1997). Topographie des Fremden: Studien zur Phänomenologie des Fremden I. Frankfurt am Main: Suhrkamp. Welsch, W. (1999). Transculturality: The puzzling form of cultures today. In S. Lash \& M. Featherstone (Eds.), Spaces of culture: City, nation, world. London: Sage. 